\title{
General Psychiatry Testing a hypothesis arising from the epidemiology of schizophrenia in New Zealand
}

\author{
Graham Mellsop, Rees Tapsell, David Benjamin Menkes ${ }^{\odot}$
}

To cite: Mellsop G, Tapsell R, Menkes DB. Testing a hypothesis arising from the epidemiology of schizophrenia in New Zealand. General Psychiatry 2019;32:e100048. doi:10.1136/ gpsych-2019-100048

Received 04 January 2019 Revised 07 February 2019 Accepted 10 February 2019
Check for updates

(C) Author(s) (or their employer(s)) 2019. Re-use permitted under CC BY-NC. No commercial re-use. See rights and permissions. Published by BMJ.

Department of Psychological Medicine, University of Auckland, Waikato Clinical School, Hamilton, New Zealand

Correspondence to Professor David Benjamin Menkes;

david.menkes@auckland.ac.nz
A 2011 publication in World Psychiatry thoughtfully, but somewhat pessimistically, addressed the question of how schizophrenia might be prevented. ${ }^{1}$ A review of causal evidence $^{2}$ a decade later offers little further hope. We hypothesise that an emergent increase in syndromal schizophrenia in New Zealand, particularly in Maori (descendants of the indigenous Polynesian population), may present opportunities for prevention.

The concept and epidemiology of schizophrenia have generally recognised it as a syndrome, rather than a disease or specific illness. Many theories of aetiology or pathogenesis have been enthusiastically propounded, often to fall by the wayside as unconfirmed or as only minor contributors to pathogenesis. Variable genetic predisposition with multiple possible environmental triggers has been the main fallback position. ${ }^{3}$

In recent years two groups of researchers have attempted to quantify the relative epidemiology of schizophrenia in New Zealand Maori (15\% of the population) and non-Maori. ${ }^{45}$ Using quite different research designs, the researchers both demonstrate significantly increased prevalence and incidence of schizophrenia in Maori compared with the remainder of the New Zealand population. The reported two to threefold increased incidence far exceeds a plausible contribution of misdiagnosis arising from cultural factors. Moreover, there is no evidence that this ethnic imbalance in incidence and prevalence existed prior to the turn of the century. Notably, the increases are at double the rate in Maori compared with non-Maori $(71 \%$ vs $35 \%)$ in the context of observed population-corrected increases in mental health service use in the first 16 years of this century (data provided by the New Zealand Ministry of Health). When analysis is limited to those discharged from inpatient services with a diagnosis of schizophrenia (F20 in the
International Classification of Diseases 10th Revision), the increases are $85 \%$ and $54 \%$, respectively. Thus, in the absence of significant changes in mental health service availability, there is good evidence of increased mental health service delivery to people diagnosed with schizophrenia, particularly in the Maori population.

A prospective Swedish study ${ }^{6}$ published in The Lancet in 1987, and more recently replicated by others, ${ }^{78}$ identified the ability of some illicit drugs, particularly amphetamines and potent cannabinoids, to produce a disorder mimicking schizophrenia in course and chronicity. Accordingly, a proportion of patients with syndromal schizophrenia experience the disorder as a consequence of drug use. With both cannabinoids and methamphetamine, the increased risk of schizophreniform psychosis is dose-related, ${ }^{9}$ and thus depends on both frequency and quantity of use.

It is now clear that the availability and use of methamphetamine in particular has risen markedly in New Zealand over the last 10 years. A New Zealand Police Insight Report of April 2018 notes that the numbers arrested and detained while under the influence of methamphetamine increased approximately tenfold between 2010 and 2017 (data provided by the New Zealand Health Quality \& Safety Commission). Also of note is the observation that the tetrahydrocannabinol content, and thus psychoactive potency, of New Zealand cannabis has increased markedly since $1996 .{ }^{10}$ A major study of the community prevalence of mental disorders in $\mathrm{New}$ Zealand found substance abuse significantly over-represented in Maori. ${ }^{11}$ Dharmawardene and Menkes ${ }^{12}$ also found cannabis use/ abuse twice as common in a Maori compared with non-Maori clinical population.

The correlational evidence strongly suggests that significant increases in the availability 
of potent cannabinoids and methamphetamine may be related to the apparent surge in the rate of schizophrenia in the general population of New Zealand and particularly to the now apparent greater rate in those of Maori ethnicity. These associations are consistent with those suggested previously regarding clinical populations in Japan, China, various European countries, and Brazil. ${ }^{13-16}$ While correlation does not establish causality, the apparent dose-response relationship ${ }^{9}$ supports causal inference as does the fact that the findings are consistent across changes in time, place and culture.

Although adequately powered, prospective, longitudinal studies will be required to establish causality, we propose that the available correlational evidence is sufficiently strong to encourage the planning and commitment of resources to relevant preventive measures.

Contributors The work was jointly conceived, drafted and revised by all three authors.

Funding The authors have not declared a specific grant for this research from any funding agency in the public, commercial or not-for-profit sectors.

Competing interests None declared.

Patient consent for publication Not required.

Provenance and peer review Not commissioned; externally peer reviewed.

Open access This is an Open Access article distributed in accordance with the Creative Commons Attribution Non Commercial (CC BY-NC 4.0) license, which permits others to distribute, remix, adapt, build upon this work non-commercially, and license their derivative works on different terms, provided the original work is properly cited and the use is non-commercial. See: http://creativecommons.org/ licenses/by-nc/4.0

\section{REFERENCES}

1 Klosterkötter J, Schultze-Lutter F, Bechdolf A, et al. Prediction and prevention of schizophrenia: what has been achieved and where to go next? World Psychiatry 2011;10:165-74.
2 Radua J, Ramella-Cravaro V, loannidis JPA, et al. What causes psychosis? An umbrella review of risk and protective factors. World Psychiatry 2018;17:49-66.

3 Jablensky A, Sartorius N, Ernberg G, et al. Schizophrenia; manifestation, incidence and course in different cultures. a world Health Organisation Ten-Country study. Psychol Med 1992. Monograph Supplement 20.

4 Kake TR, Arnold R, Ellis P. Estimating the prevalence of schizophrenia among New Zealand Maori: a capture-recapture approach. Aust N Z J Psychiatry 2008;42:941-9.

5 Tapsell R, Hallett C, Mellsop G. The rate of mental health service use in New Zealand as analysed by ethnicity. Australas Psychiatry 2018;26:290-3.

6 Andréasson S, Engström A, Allebeck P, et al. Cannabis and schizophrenia a longitudinal study of Swedish conscripts. The Lancet 1987;330:1483-6.

7 Paparelli A, Di Forti M, Morrison PD, et al. Drug-induced psychosis: how to avoid StAR gazing in schizophrenia research by looking at more obvious sources of light. Front Behav Neurosci 2011;5:1-7.

8 Murray RM, Quigley H, Quattrone D, et al. Traditional marijuana, high-potency cannabis and synthetic cannabinoids: increasing risk for psychosis. World Psychiatry 2016;15:195-204.

9 Arunogiri S, Foulds JA, McKetin R, et al. A systematic review of risk factors for methamphetamine-associated psychosis. Aust $N Z J$ Psychiatry 2018;52:514-29.

10 Knight G, Hansen S, Connor M, et al. The results of an experimental indoor hydroponic cannabis growing study, using the 'Screen of Green' (ScrOG) method-Yield, tetrahydrocannabinol (THC) and DNA analysis. Forensic Sci Int 2010;202:36-44.

11 Browne O, Wells JE, Scott KM. Te rau Hinengaro: the New Zealand mental health survey. Wellington: Ministry of Health, 2006: Pp 151-2.

12 Dharmawardene V, Menkes DB. Substance use disorders in New Zealand adults with severe mental illness: descriptive study of an acute inpatient population. Australas Psychiatry 2015;23:236-40.

13 Yui K, Ikemoto S, Ishiguro T, et al. Studies of amphetamine or methamphetamine psychosis in Japan: relation of methamphetamine psychosis to schizophrenia. Ann N Y Acad Sci 2000;914:1-12.

14 Pinto R, Ashworth M, Jones R. Schizophrenia in black Caribbeans living in the UK: an exploration of underlying causes of the high incidence rate. Br J Gen Pract 2008;58:429-34.

15 Deng X, Huang Z, Li X, et al. Long-term follow-up of patients treated for psychotic symptoms that persist after stopping illicit drug use. Shanghai Arch Psychiat 2012;24:271-7.

16 Di Forti M, Quattrone D, Freeman TP, et al. The contribution of cannabis use to variation in the incidence of psychotic disorder across Europe (EU-GEI): a multicentre case-control study. Lancet Psychiatry 2019. doi:10.1016/S2215-0366(19)30048-3. [Epub ahead of print: 19 Mar 2019].

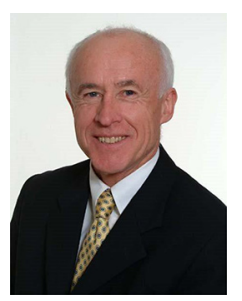

Graham Mellsop graduated in medicine from the University of Otago in New Zealand in 1966. He has held professorial positions at four Australian and New Zealand universities since 1982 with a publication research career particularly in the areas of psychiatric epidemiology, medical education, and law and psychiatry. During that time he has provided many educational and service development consultancies in Asian and Pacific countries, including for the World Health Organisation and Chinese and Malaysian Universities. In the last 20 years his employment has been at the Waikato Clinical Campus of the University of Auckland where many of his academic activities have been culturally informed by Maori co-workers. Currently he has continuing research interest in the epidemiology of syndrome schizophrenia, its optimal clinical management, and the interface of law and psychiatry. 